\title{
JAPONIA I POLSKA W LATACH 1918-1941
}

Ewa Pałasz-Rutkowska, ,Polityka Japonii wobec Polski 1918-1941", Warszawa 1998, Zakład Japonistyki i Koreanistyki. Instytut Orientalistyczny, Uniwersytet Warszawski.

Jest to kolejna ${ }^{1}$ praca tej autorki traktująca o stosunkach polsko-japońskich, ale przedstawiająca je z punktu widzenia Japonii. Autorka zbadała kształtowanie się polityki Japonii wobec Polski w latach 1918-1941, tj. w japońskim okresie międzywojennym wykazując, że odległa zarówno pod względem geopolitycznym, jak i kulturowym Rzeczpospolita była z wielu powodów atrakcyjna dla Wielkiego Cesarstwa Japonii. Politykę Japonii wobec Polski autorka ukazała na tle japońskiej polityki zagranicznej, co pozwala czytelnikowi lepiej zrozumieć, jak zmiany zachodzące na Dalekim Wschodzie wpływały na postawy obu krajów. Największy wpływ na stosunki między obu państwami miały stosunki Japonii z Rosją i Niemcami. Lata 1918-1941 to najciekawszy okres w 80-letniej historii stosunków polskojapońskich. Rok 1918 to koniec I wojny światowej, po której nastąpiło uznanie niepodległego państwa polskiego przez większość państw Zachodu. Japonia zrobiła to dopiero w marcu 1919 roku, po kilkumiesięcznej obserwacji młodego państwa polskiego. W roku 1941 (w październiku) miało miejsce zamknięcie ambasady RP w Tokio, i to na wyraźne żądanie sojusznika Japonii - Niemiec.

Książka składa się z wprowadzenia, czterech rozdziałów, traktujących chronologicznie historię stosunków japońsko-polskich 1918-1941 i zakończenia, bibliografii oraz aneksów, zawierających przegląd premierów i ministrów spraw zagranicznych Japonii w latach 1914-1941, szefów japońskiej misji dyplomatycznej w Warszawie w latach 1921-1941, japońskich attache wojskowych w Polsce 1921-1941, wreszcie indeksu nazwisk i indeksu wybranych Terminów japońskich. Autorka dotarła do wielu niepublikowanych dotąd materiałów, głównie pochodzących z Ministerstwa Spraw Zagranicznych Japonii. Analiza tych materiałów wskazuje, że w kołach politycznych Japonii istniały dwa nurty w podejściu do Polski. O ile poli-

Patrz: Ewa Palasz-Rutkowska, Andrzej T. Romer, Historia stosunków polskojapońskich, Warszawa: Bellona, 1996, s. 272. Biblioteka Fundacji im. Takashimy. 
tycy byli ostrożni, tak wojskowi, szczególnie zaś szefowie sił lądowych, widziel w Polsce partnera do walki najpierw z Rosją Sowiecką, a potem w inwigilacji Niemiec, wojskowego i politycznego sojusznika Japonii. W historycznym wstępie skrótowo przedstawiona została pozycja Japonii na arenie międzynarodowej $\mathrm{w}$ latach 1868-1914, tj. od restauracji Meiji do wybuchu I wojny światowej. Był to najważniejszy okres w kształtowaniu nowoczesnej świadomości Japonii. Z głębokiego feudalnego zacofania Japonia szybko wkroczyła na arenę międzynarodową, zaznaczając swoją obecność szeregiem bezkrwawych podbojów i zagrażając interesom osiadłych już na Dalekim Wschodzie mocarstw Anglii, Francji, Niemiec i Rosji. Jednak nie można się zgodzić z opinią autorki, że wkrótce po modernizacji Japonia „,szybko stała się bogatym krajem o sprawdzonej w wojnach silnej armii, który swymi wpływami objął także Tajwan, Peskadory, Liaondong, Koreę i południową część Sachalinu" (s. 24-25). Japonia szybko się rozwijała, ale o dogonieniu czołowych mocarstw Zachodu nie mogło wówczas być mowy, a imperialny kurs w polityce zagranicznej wynikał nie z bogactwa Japonii, ale z jej biedy. Druga połowa XIX w. jest okresem ogromnej migracji Japończyków. Na Hawajach (w 1885 r. mieszkało tam już 30 tys. Japończyków, co stanowiło 40\% mieszkańców wysp), w Brazylii, w Kalifornii szukali oni możliwości poprawy swego bytu. Japonia zaczęła być bogata dopiero w latach sześćdziesiątych naszego wieku. W latach dziewięćdziesiątych osiągnęła dochód narodowy na głowę jednego mieszkańca archipelagu ponad 33 tys. USD (w 1997 - 33,319 dol., w tym samym czasie w USA - 30.160 dol.), podczas gdy w roku 1887 tzw. dochód społeczny wynosił $235 \mathrm{mln}$ jenów (przy liczbie ludności około $41 \mathrm{mln}$ ) [dane za: Anten Zischka, Japonia, Trzaska, Evert i Michalski S.A., Warszawa, wydanie przedwojennej. Bez wątpienia prawdą jest, że w biednym społeczeństwie japońskim końca ubiegłego wieku najbogatsza i najsilniejsza była armia. Stanowiła ona jeden z filarów władzy i narzędzie ekspansji rządzących elit, które przy jej pomocy realizowały swe ambicje polityczne na zewnątrz wysp japońskich. Osiągały sukcesy, bo zasiedziałym na Dalekim Wschodzie mocarstwom wydawało się niemożliwe, by mogło im zagrażać państwo, któremu w latach 1854-1861 narzucono szereg niepełnoprawnych traktatów i które uważano za państwo drugiej kategorii. Stąd pierwsze podboje Japonii nie wywołały specjalnego oburzenia mocarstw zachodnich. Japonia bez przeszkód zagarnęła w 1870 r. Wyspy Bonin i Wulkaniczne, w 1872 r. włączyła do swego terytorium archipelag Riukiu z największą wyspą Okinawą (w 1879 dokonała ich inkorporacji). W latach siedemdziesiątych usiłowała też zdobyć wpływy w Korei. W 1874 rozpoczęła okupację Formozy (którą prawnie przejęła na mocy traktatu z 1895, po pokonaniu Chin na morzu) i opanowała Peskadory. Dopiero jednak wojna japońsko-chińska na morzu w latach 1894-95 i zdobycze terytorialne Japonii na kontynencie wywołały niepokój mocarstw zachodnich, które nie chciały jej „obecności" na terytorium Chin na takich samych równorzędnych z mocarstwami europejskimi i USA prawach.
Z bogatej literatury wykorzystanej w tej pracy przez autorkę, z dużą ostrożnością potraktować należy pozycję, na którą chętnie się powołuje omawiając politykę zagraniczną Japonii okresu 1894-1922, a szczególnie jej trzytomowa, angielską wersję — The Diplomacy of Japan 1894-1922, Tokyo 1976. Praca wydana przez Instytut Pokojowy Kajimy (The Kajima Institute of International Peace) powstała pod kierunkiem byłego japońskiego dyplomaty, późniejszego biznesmena i polityka - Morinosuke Kajimy (1896-1975). W The Diplomacy of Japan Kajima i jego 15-osobowy zespół, złożony z byłych dyplomatów kierowanych przez byłego ministra spraw zagranicznych, świadomie wybiela imperialną politykę Japonii lat 1894-1922. W angielskiej przedmowie do tej pracy Kajima stwierdza, że chociaż Japonia w okresie ostatniego stulecia prowadziła cztery wojny: z Chinami, z Rosja, brała udział w I i II wojnie światowej, to ,rzeczywista intencją dyplomacji japońskiej w okresie tych wojen było przyczynienie się do pokoju i dobrobytu $\mathrm{w}$ Azji w szczególności, i w całym świecie".

Wydaje się, że dla badacza stosunków międzynarodowych takie źródło ma wątpliwą wartość naukową. Badając politykę zagraniczną jakiegokolwiek państwa, zwłaszcza jego burzliwych okresów, niekiedy ryzykowne jest korzystanie, czy powoływanie się na autorów wywodzących się z kręgów politycznych badanego kraju. Znamy z historii wiele przypadków fałszowania, wybielania i usuwania niewygodnych faktów historycznych. Podobną sytuacje mamy w przypadku wyżej wymienionej książki. Przemilczano w niej np. informacje o „Dwudziestu jeden żądaniach", które Tokio skierowało w 1915 r. pod adresem Chin. Ponadto praca powstała ponad pół wieku po opisywanych zdarzeniach i w wielu przypadkach jest kompilacją różnych dokumentów, a jej autorzy (już ludzie starzy) „dorabiali" historyczną analizę do przyjętych przez siebie założeń. Na Zachodzie książka ta została przyjęta krytycznie i z wielką ostrożnością potraktowana przez japońskie kręgi naukowe.

Książka Ewy Pałasz-Rutkowskiej wypełnia lukę w historiografii naszych dziejów najnowszych. Stanowi ciekawe źródło wiedzy o stosunkach między tak od siebie oddalonymi krajami. Wydaje się jednak, że jest skierowana do wạskiego grona specjalistów - zawiera wiele japońskich terminów, nazw i znaków, a to polskiemu czytelnikowi może sprawić pewna trudność w plynnym jej pa temat polityki zagranicznej w tym okresie „zob. m.in. Gaimuhono hyakunen, Tokyo 1968" przypis na s. 22, czy przypis 43 na s. 26: „,szczegóły na temat podróży zob.: Fukushimashogun iseki, Tokyo 1941". Ponadto swojej roli nie spełnia odsyłanie do źródeł poprzez podanie numeracji stron: np. 31-293, 177-293, 293-357, 401-453 (przypisy na stronie 21 i 22), bo to tak jakby nigdzie.

Elżbieta Potocka 